\title{
Relation of smoking parameters to the yield, colour and sensory quality of smoked Atlantic salmon (Salmo salar)
}

\author{
Mireille Cardinal ${ }^{\mathrm{a}^{\star}}$, Camille Knockaert ${ }^{\mathrm{a}}$, Ole Torrissen ${ }^{\mathrm{b}}$, Sjofn Sigurgisladottir ${ }^{\mathrm{c}}$, Turid Mørkøre ${ }^{\mathrm{d}}$, \\ Magny Thomassen ${ }^{\mathrm{e}}$ and Jean Luc Vallet ${ }^{\mathrm{a}}$
}

\footnotetext{
a Laboratoire Génie Alimentaire, IFREMER, rue de l'île d'Yeu, BP 21105, 44311 Nantes cedex 3, France

${ }^{b}$ Institute of Marine Research, Austevoll Aquaculture Research Station, N-5392 Storebo, Norway

${ }^{c}$ Matra, Technological Institute of Iceland, Keldnaholt, IS-112, Iceland

${ }^{d}$ AKVAFORSK, Institute of Aquaculture Research Ltd, PO Box 50 10, N-1432 Aas, Norway

e Department of Animal Science, Agricultural University of Norway, PO Box 5025, N-1432, Aas, Norway

* cardinal@ifremer.fr Tel.: +33-2-40-37-40-00; fax: +33-2-40-37-40-71;
}

\begin{abstract}
The relations between smoking parameters and the characteristics of salmon raw material were investigated with respect to yield, colour, flesh content of phenol and salt, and sensory properties. The fish studied were ocean ranched salmon harvested in Iceland in July 1998 and farmed salmon from Norway slaughtered in October 1998 and April 1999. Seven treatments were applied on fresh or frozen raw material combining dry or brine salting with cold smoking at 20 or $30^{\circ} \mathrm{C}$. Electrostatic smoking was tested on dry-salted salmon fillets. The results show a lower yield after filleting and trimming with ocean ranched fish. Although freezing had little effect on yield, total loss was slightly greater, especially for fish with low fat content. Sensory differences were also apparent. The brine salting technique resulted in lower losses. Fish with higher fat content gave a better yield after processing, although careful control of the smoking procedure was required (especially at $30^{\circ} \mathrm{C}$ ) to avoid a case-hardening effect. With brine salting, salt uptake was higher for smaller, leaner fish. The phenol content of flesh depended on the technique and/or smoking temperature used, regardless of the fish studied. However, for a smoking temperature of $30^{\circ} \mathrm{C}$, the flesh of smaller, leaner fish showed a higher phenol level. Smoking conditions and preliminary treatment such as freezing produced similar differences in sensory characteristics, regardless of the fish studied, although smaller, leaner individuals appeared to be more sensitive to these processes.
\end{abstract}

Keywords: Atlantic salmon; Smoking; Yield; Salting; Freezing; Quality parameters 


\section{Introduction}

Important changes in food consumption and distribution systems during the second half of the $20^{\text {th }}$ century have been associated with extensive industrialisation of production structures. In this context, smoked salmon, which was initially regarded as a luxury product, has gradually become an element of general consumption. Initially produced in the 1920s in salt-dried, cold-smoked form by simple tradesmen, it has now become an industrial product on a highly developed market (Monfort, 1999). The development of aquaculture of the Atlantic salmon (Salmo salar) has contributed very largely to commercial growth (Roberts, 1998; Hempel, 1998, 1999), allowing producers of smoked salmon to have ready access (less than 6 days) to fresh raw material of uniform quality available year-round.

As the cost of this raw material accounts for a large part of total production costs, firms need to seek supplies of fresh salmon from highly diversified markets. For France, the raw material is mainly of aquacultural origin. Although the main production areas in Europe for Atlantic salmon are in Scandinavian countries, the rearing procedures can vary considerably from one country to another and from one farm to another. These variability factors are numerous and concern rearing conditions as well as slaughtering, packaging and transport (Torrissen, 1995). Moreover, the processing firms now have a large choice of equipment for better control of production parameters. Thus, the producer must have perfect knowledge of the raw material and the effects of the processes used, so that the characteristics of the finished product will be consistent with market demand and profitability requirements.

Several factors are involved in this notion of profitability and production control (Sigurgisladottir, Torrissen, Lie, Thomassen \& Hafsteinsson, 1997). The most important ones are processing yields and a respect for the characteristics of the finished product. The latter, independently of health considerations, concern chemical (salt, water, lipid and phenol contents), physical (texture and colour) and sensory aspects.

For smoked salmon, yield and quality are related to the operations involved in fillet production, such as head removal, filleting and trimming (Rorå, Kvale, Morkore, Rorvik, Steien \& Thomassen, 1998), the choice of the processes used (salting, drying and smoking techniques), and the parameters relating to these processes, such as brine concentration, length of treatment, temperature or hygrometry (Chan, Toledo \& Deng, 1975; Horner, 1993), all of which are closely dependent on the characteristics of the raw material.

Various studies have been performed concerning the optimisation of salting, drying and smoking processes (Le Gall, 1938; Knockaert, 1990; Doe, 1998) and the quality of fresh (Aursand, Bleivik, Rainuzzo, Jorgensen \& Mohr, 1994; Hillestad, Austreng \& Johnsen, 1995; Sigholt, Erikson, Rustad, Johansen, Nordtvedt, 
\& Seland, 1997; Berg, Erikson \& Nordtvedt, 1997) and smoked Atlantic salmon (Rorå et al., 1998; Wang, Tang \& Correia, 2000; Indrasena, Hansen, \& Gill, 2000).

Thus, the size and shape of fish have an effect on processing yields (Rorå et al., 1998) and the choice of processing parameters. Likewise, lipids in flesh play an important role as a limiting factor during the salting and drying steps (Jason, 1965a; Bohuon, 1995), either replacing the aqueous phase that serves as a vector for transfers during these steps or acting as a physical barrier. On the contrary, the presence of lipids during the smoking step is a positive factor for the uptake of smoke compounds (Korhonen, Reagan, Carpenter, Campion, \& Stribling, 1978; Beltran \& Moral, 1991).

The purpose of the present study was to detect and analyse interactions between the characteristics of the raw material and certain processing parameters relative to the yields and quality of smoked salmon. Two salting techniques (brine or dry salt) were associated with two cold smoking temperatures (20 and $\left.30^{\circ} \mathrm{C}\right)$. The deposition of smoke compounds by an electrostatic smoking method was also studied, as well as the effect of freezing the raw material. Our intention was to propose technical recommendations for better control of the finished product based on a relevant choice of the characteristics of the raw material with respect to the processes available.

This study is part of a larger undertaking within the scope of European Union FAIR project No. CT 951101 (“Interaction between raw material characteristics and smoking process on quality of smoked salmon”) coordinated by the Icelandic Institute (Matra) in association with the Instituto del Frio (Spain), the Institute of Marine Research (Norway), the Institute of Nutrition (Norway), Akvaforsk (Norway) and IFREMER (France).

\section{Materials and Methods}

\subsection{Materials}

\subsubsection{Animal material}

Three groups of 105 fish each, from different origins and with different rearing characteristics as described by Sigurgisladottir, Ingvarsdottir, Torrissen, Cardinal \& Hafsteinsson (2000), were compared in this study. The first sample (Group A) was obtained from ocean ranched salmon harvested in July 1998 in Iceland. The average weight of these fish was $2.6 \mathrm{~kg} \pm 300 \mathrm{~g}$ (individuals weighing $4 \mathrm{~kg}$ were expected, but proved impossible to obtain because of planning problems). In these conditions, no sorting according to weight was performed. The second sample consisted of farmed salmon harvested in October 1998 (Group B) with an average weight of $4 \mathrm{~kg}$ 
\pm 150 g. The third group, also consisting of farmed salmon, was harvested in Norway in April 1999 (Group C)

and had an average weight of $3.7 \mathrm{~kg} \pm 500 \mathrm{~g}$.

All fish were harvested by netting and bled by cutting the gill arches on one side. After a bleeding step in cold seawater, salmon were gutted, cleaned and individually weighed and tagged. Fish were placed on ice in sealed boxes, shipped to AKVAFORSK for fat determination and then transported by refrigerated truck to IFREMER (French Research Institute for the Exploitation of the Sea) in Nantes, France. The delay between slaughtering and the beginning of treatment was 7 days.

To study the effect of freezing, 30 fish within each group were sent to Nantes one month earlier and were frozen (1 hour) with cryogenic equipment $\left(\mathrm{CO}_{2}\right.$ at $\left.-60^{\circ} \mathrm{C}\right)$ and stored at $-20^{\circ} \mathrm{C}$. A thawing step in air was performed at $4^{\circ} \mathrm{C}$ for $24 \mathrm{~h}$.

\subsubsection{Processing equipment}

Two different techniques were compared for drying and smoking salmon fillets. The traditional method used an HMI Thirode (PC90 Model) apparatus with a capacity of $380 \mathrm{~kg}$ mounted on a trolley with 28 grids. The smokehouse measured 150 × 130 × $225 \mathrm{~cm}$, and air/smoke circulation was horizontal. The airflow rate and relative humidity were controlled. Smoke was produced with a generator by pyrolysis $\left(450^{\circ} \mathrm{C}\right)$ of sawdust from beechwood and sustained airflow (Thirode, France). The electrostatic smoking method (Collignan, Knockaert, Raoult-Wack \& Vallet, 1992, 1993; Bardin, Desportes, Knockaert \& Vallet, 1997) was performed using an experimental tunnel $3 \mathrm{~m}$ long, $35 \mathrm{~cm}$ wide and $20 \mathrm{~cm}$ high. This allowed continuous smoking at ambient temperature, with a production capacity of $125 \mathrm{~kg} / \mathrm{h}$. Tension applied between the positive pole (smoke ionisation) and the cathode (conveyor belt) was $40 \mathrm{kV}$. Air speed above the fillets was $0.5 \mathrm{~m}^{-1}$, and relative humidity around 70\%. Smoke was obtained from a friction generator (Muvero, Netherlands) using oak beam at a temperature of $350^{\circ} \mathrm{C}$.

\subsection{Methods}

\subsubsection{Sample preparation}

Gutted fish were weighed and filleted. Each fillet was trimmed by hand and processed according to the preparation scheme in Figure 1. Each group of 105 fish was processed according to seven different treatments, including different salting and smoking techniques. Fifteen salmon were used for each procedure, and fillet weight was recorded at each step to calculate yields. 
Figure 1. Process steps

Whole gutted salmon (Salmo salar)

A. Ocean ranched (average weight $2.6 \mathrm{~kg}$ ), July 1998

B. Farmed salmon from northern Norway (4 kg), October 1998

C. Farmed salmon from western Norway (3.7 kg), April 1999

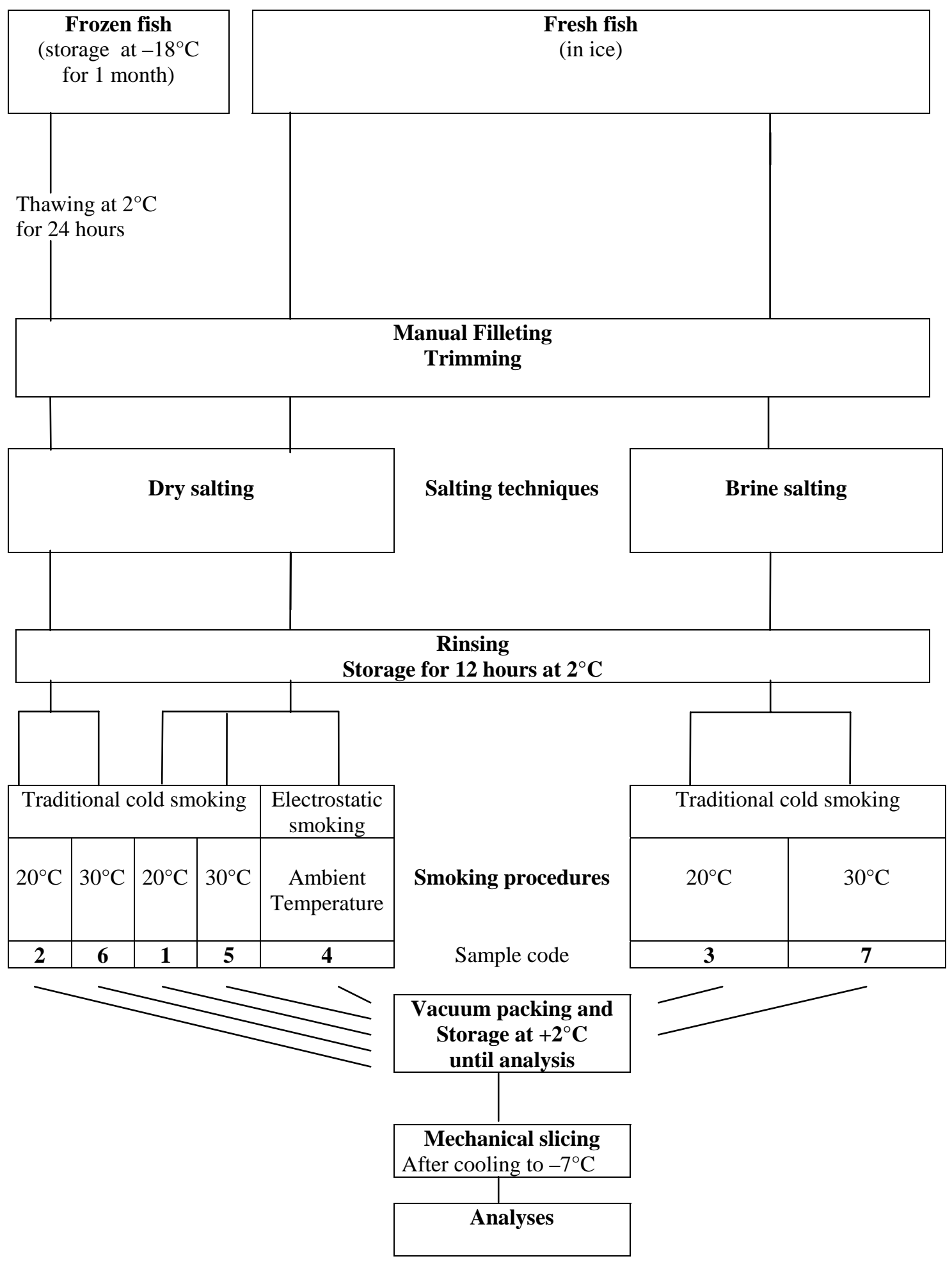




\subsubsection{Salting}

Two salting techniques were studied. The first was a dry salting technique in which fillets salted by hand with

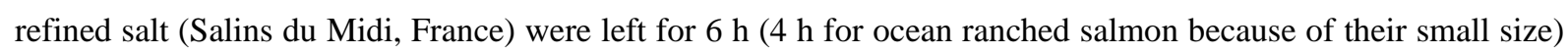
at $12^{\circ} \mathrm{C}$. The fillets were then rapidly rinsed with water $\left(15^{\circ} \mathrm{C}\right)$ on grids and stored in a cold room at $2{ }^{\circ} \mathrm{C}$ until smoking.

The brine salting technique used saturated brine $(360 \mathrm{~g} / \mathrm{l})$ maintained $a t 12^{\circ} \mathrm{C}$ in which the fillets were placed [ratio 50/50 (w/v)]. After $6 \mathrm{~h}$ (4 h for ocean-ranched salmon), the fillets were removed, rapidly rinsed and stored overnight (12 h) in a cold room at $2^{\circ} \mathrm{C}$ until smoking. Fillets were weighed before smoking.

\subsubsection{Drying - Smoking}

A traditional cold-smoking process was carried out at two different temperatures in accordance with industrial practices based on different materials (Knockaert, 1990). After storage for $12 \mathrm{~h}$ at $+2^{\circ} \mathrm{C}$, the smoking process began with a drying step in the smoking oven for $30 \mathrm{~min}$ at $20^{\circ} \mathrm{C}$, followed by a smoking step at $20^{\circ} \mathrm{C} \pm 1^{\circ} \mathrm{C}$, with a relative hygrometry of $65 \% \pm 3 \%$ and air speed of $2 \mathrm{~ms}^{-1}$ above the products and $18 \mathrm{~ms}^{-1}$ at the end of the air channel. Smoking was performed for $2.5 \mathrm{~h}$. The same procedure was carried out for fish smoked at $30^{\circ} \mathrm{C}$, with a relative humidity of $50 \%$. With electrostatic smoking, fillets were maintained at $+2^{\circ} \mathrm{C}$ for $12 \mathrm{~h}$ and then placed in the smoking tunnel for $15 \mathrm{~min}$.

\subsubsection{Slicing and packaging}

One day before sensory sessions and chemical analyses, fillets were frozen by the cryogenic method (Airgaz) for $20 \mathrm{~min}$ at $-60^{\circ} \mathrm{C}$ to an inner temperature of $-7^{\circ} \mathrm{C}$ and mechanically sliced (PNP, France). Skin was removed before slicing. Sliced fillets were immediately vacuum-packed (Boulanger, France). Samples were stored at $+2^{\circ} \mathrm{C}$ until analysis.

\subsubsection{Analytic methods}

\subsubsection{Yield measurement}

Filleting and trimming loss $=100 *$ (gutted weight of fish - weight after filleting and trimming) / gutted weight of fish

Salting loss $=100 *$ (fillet weight after filleting and trimming - fillet weight after salting) / fillet weight after filleting and trimming 
Smoking loss $=100 *$ (fillet weight after salting - fillet weight after smoking) $/$ fillet weight after salting

Total loss after salting and smoking $=100 *$ (fillet weight after filleting and trimming - fillet weight after smoking) / fillet weight after filleting and trimming.

Relative loss after salting = (weight loss after salting/weight after salting and smoking)*100

Relative loss after smoking $=$ (weight loss after smoking/weight after salting and smoking)*100

\subsubsection{Chemical analyses}

Total fat content was determined on gutted fish by non-destructive computer-assisted X-ray tomography, as described by Rye (1991). The correlation equation between data from X-ray tomography and data from chemical analysis allowed fat content values to be expressed as classical chemical results. Dry matter content was analysed by oven drying of $2 \mathrm{~g}$ of smoked salmon at $105^{\circ} \mathrm{C}$ until a constant weight was reached and salt content was measured with Chloride Analyser 926 (Corning, Halstead, England). Total phenols were quantified by the method described in the French standard for smoked salmon (NF V 45-065, 1995). All these analyses were performed on the front part of each smoked fillet.

\subsubsection{Sensory evaluation}

Descriptive and quantitative analysis (Stone et al., 1974; Stone \& Sidel, 1985) was performed to evaluate the sensory characteristics of smoked salmon. Twenty panellists belonging to the IFREMER staff, selected for their interest, availability and sensorial capacities, were trained on sensory descriptors chosen during a preliminary step, according to the international procedure, NF ISO 11035 (1994). Three training sessions for profiling were organised to check the panellists' understanding of the descriptors and analyse performances of each assessor before starting the study. The descriptors chosen related to the appearance, odour, flavour and texture of smoked salmon slices: odour: smoke intensity, wood fire, acrid smell of smoke, toasted bread, fresh salmon; appearance: pink colour, orange colour, homogeneity of colour; darkness of the slice edge, translucent appearance, fatty aspect, white stripes; flavour: smoke intensity, wood fire, salty taste, fresh salmon; and texture: firmness, melting texture, fatty texture, pasty texture.

Four sessions were proposed to the panel for each raw material. Samples smoked at $20^{\circ} \mathrm{C}$ and those smoked with the electrostatic process were evaluated twice, after 8 and 9 days of storage at $2^{\circ} \mathrm{C}$. Salmon smoked at $30^{\circ} \mathrm{C}$ were also scored twice, after 12 and 13 days. Samples dry-salted and smoked at $20^{\circ} \mathrm{C}$ were used as a common reference in these four sessions. Because samples were stored at $2^{\circ} \mathrm{C}$, they were considered to keep the same 
characteristics between 8 and 13 days of storage. Each panellist received two slices taken from the third front part of a fish. Seven or eight fish were used for each session.

Sessions were performed in individual partitioned booths equipped with a computerised system (Fizz system, Biosystèmes, Dijon, France). These conditions were conducive to concentration and avoided communication between assessors and disturbance by external factors (AFNOR NF V-09-105, 1995). Panellists rated the sensory attributes on a continuous scale presented on a computer screen, from low intensity (0) to high intensity (10). Products were assigned 3-digit numbers, randomised and served simultaneously. Twelve sessions were organised to test all the raw material and processes.

\subsubsection{Colour measurement}

Colour was determined by a Hunterlab miniscan XE using the D65 light source and a $10^{\circ}$ observer. Reflectance from 400 to $700 \mathrm{~nm}$ was recorded as well as $\mathrm{L}^{*}, \mathrm{a}^{*}, \mathrm{~b}^{*}$ according to International Commission on Illumination, CIE, (1976). Colour was measured in the anterior, median and posterior parts of the dorsal and ventral side of raw and smoked fillet. Results are shown as the mean of six measurements per fish fillet.

\subsubsection{Statistical analysis}

The mean, standard deviation, analysis of variance and Duncan's multiple range test were performed using Statgraphics Plus software (Sigma Plus, Paris, France). The significant statistical level was set at $\mathrm{p}<0.05$. Multivariate data processing was performed with Uniwin Plus 3 software (Sigma Plus, Paris, France). To adjust for variations among assessors in the scoring range, sensory data were standardised using an isotropic scaling factor according to the procedure proposed by Kunert \& Qannari (1999). Scores of the dry-salted product smoked at $20^{\circ} \mathrm{C}$ were used as a reference at each session, thereby allowing data from different sessions to be compared.

The study of differences between samples was done by analysis of variance on each descriptor, and principal component analysis was performed on the means of these data. 


\section{Results-Discussion}

\subsection{Influence of raw material and processing on yields}

\subsubsection{Raw material effect on loss after filleting and trimming}

Flesh lipid content showed significant differences among the three raw materials: 9.4\%, 20.0\% and $16.8 \%$ of wet weight respectively for ocean ranched salmon, farmed salmon slaughtered in October 1998 and farmed salmon slaughtered in April 1999. Analysis of variance for loss after filleting showed a significant difference between the different raw materials. Ocean-ranched salmon from Iceland, which were smaller and leaner than the fish in the other groups, had the highest loss (Figure 2). According to Rorå et al. (1998), this result can be regarded as an effect of weight more than fat content. The difference between groups was as great as $1 \%$. Moreover, wild salmon were not sorted and weight variability in that group was greater than in the other groups. From an industrial point of view, this heterogeneity could raise problems depending on the process used.

Fig. 2. Loss after filleting and trimming for three raw materials. Group A = ocean ranched salmon (July 1998), Group B = farmed salmon (October 1998), Group C = farmed salmon (April 1999) mean values are given for each group; different letters indicate significant differences $(\mathrm{p}<0.05)$.

\section{Loss after filleting and trimming(\%)}

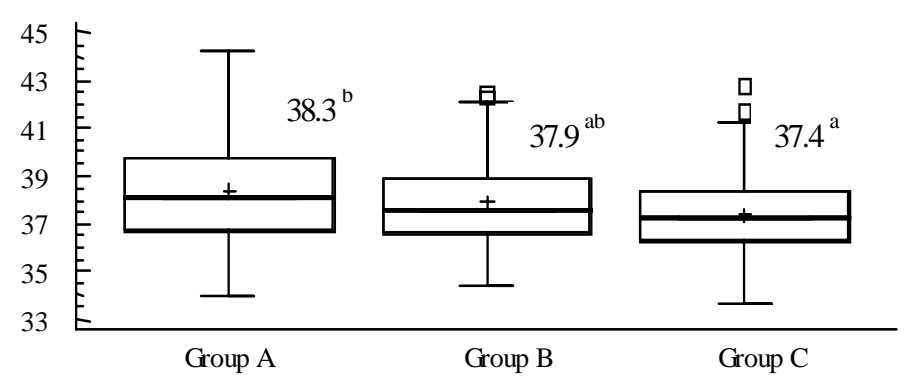

\subsubsection{Effect of freezing raw material on yields after processing}

Losses after dry salting were generally slightly higher with frozen material (Table 1). The difference in losses between fresh and frozen raw material was 0.1\% in October 1998, 0.3\% in April 1999 and reached 0.6\% in July 1998. The difference was only statistically significant in the ocean ranched group. However, losses with frozen material after dry salting were generally low compared to total loss. This may seem contradictory with the results of many previous studies indicating that all treatments affecting cell integrity, such as freezing, increase solute intakes at the expense of water (Ponting, 1973; Dussap \& Gros, 1980; Saurel, Raoult-Wack, Rios, \& Guilbert, 1994). However, in our study, the cryogenic method used for freezing, as well as the short storage period (one 
month), limited tissue destruction and allowed the raw material to be preserved and to retain its good functional properties, as reported by Sivertsvik (1994) for frozen Salmo salar. Nonetheless, if the complete process is considered, including the drying and smoking steps, total losses were greater with frozen raw material, especially for ocean ranched salmon.

After a drying/smoking step at $20^{\circ} \mathrm{C}$, the freezing step produced a significant loss of raw material. There was also a relation between the kind of raw material and freezing treatment, which indicated that loss after smoking was higher to the extent that fish were smaller and leaner. For smoking at $30^{\circ} \mathrm{C}$, losses were not affected by a freezing step (Table 1).

Table 1. Weight loss after each process step (\%). Group A = ocean ranched salmon (Iceland, July 1998), Group B = farmed salmon (October 1998), Group C = farmed salmon (April 1999) mean values are given for each group; on each row, different letters indicate significant differences $(\mathrm{p}<0.05){ }^{1}: 20^{\circ} \mathrm{C}=$ traditional cold smoking at $20^{\circ} \mathrm{C}, 30^{\circ} \mathrm{C}=$ traditional cold smoking at $30^{\circ} \mathrm{C}, \mathrm{E}=$ smoke deposit with the electrostatic method.

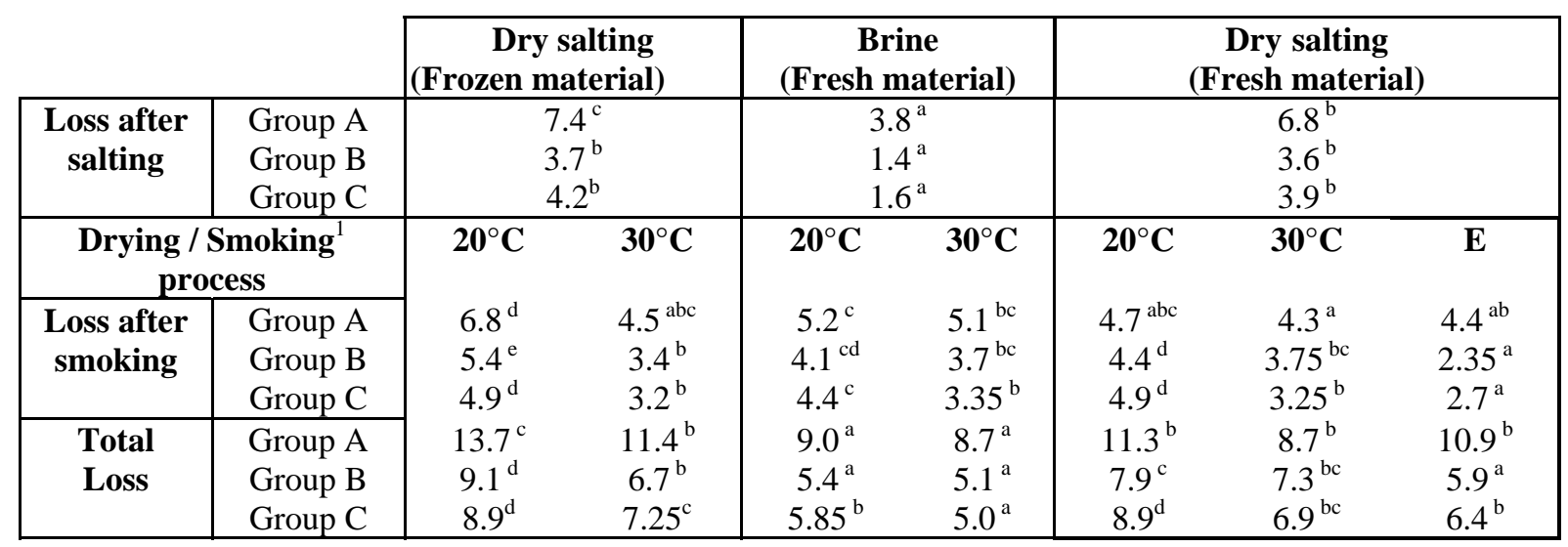

\subsubsection{Effect of the salting technique on yields after processing}

Our results showed better yields with the brine-salting than the dry-salting technique (Table 1). Solute transfer during the salting step occurs in the water phase between intracellular fluid and the outside medium (Soudan, 1955). However, depending on the kind of salting, transfers do not start in the same way. For dry salting, the water phase (which does not exist initially) has to be created by extraction of intracellular water to the surface of the product (Dieuzaide, 1951). On the contrary, for brine salting, salmon fillets are already soaked in a liquid solution, so that water diffusion is reduced and losses are lower (Table 1). The effects are greater to the extent that the raw material is lean (i.e. with high water content), as observed in group A for the loss recorded after salting. These results are in accordance with those of Boury (1934) and Jason (1965b), who demonstrated the importance of the size factor and the barrier effect of lipids. Sheehan, O’Connor, Sheehy, Buckley \& FitzGerald 
(1996) and Wang et al. (2000) also indicated that the transfer of a salted solution decreases with an increase of lipid content.

\subsubsection{Effect of the smoking technique or drying/smoking temperature on yields after processing}

From a physical point of view, drying (which occurs at the surface of the product) is due to a two-step migration of water: first, evaporation of surface water, and then the diffusion of water within the flesh toward the surface of the fillet (Cheftel \& Cheftel, 1977). One of the factors affecting the migration mechanism in flesh is the chemical composition, particularly lipid content. The speed of water diffusion in the flesh of lean fish is faster than in fat fish, which leads to more rapid drying and higher losses (Table 1). In the case of wild salmon (group A), the phenomena of surface evaporation remain at a high level during drying because of the greater quantity of water available in the fillet. This is particularly apparent in the case of brine salting for which losses are lower, so that the fillet retains a higher water content.

The drying-smoking step at $20^{\circ} \mathrm{C}$ leads to greater losses than at $30^{\circ} \mathrm{C}$. In fact, at $20^{\circ} \mathrm{C}$ the hygrometry is easier to control and drying occurs in more favourable conditions. Industrial drying, when well performed, supposes an optimal difference in hygrometry (a maximum of 10\%) between the surface of the product and ambient temperature, which can be ensured for a $20^{\circ} \mathrm{C}$ step, but is difficult to attain with $30^{\circ} \mathrm{C}$ (Knockaert, 1990). In the latter case, the hygrometric differential is around 15 to $20 \%$, which accelerates surface evaporation. In these conditions, the water diffusion rate for fat fish is lower than the rate of surface evaporation, which induces casehardening and thus a blockage of transfer and a reduction of loss occurs. This phenomenon has been described by Bimbenet (1978), who noted that too low a hygrometry associated with too high a temperature alters drying profiles. The surface of the flesh is modified by a concentration of solutes that block the capillaries and the arrival of water, thus preventing evaporation completely. This case-hardening effect can be detrimental to product quality since it prevents effective drying and can reduce product life.

For smoking at $30^{\circ} \mathrm{C}$, the results were the same whether the raw material was frozen or not. As the drying conditions were more favourable at $20^{\circ} \mathrm{C}$ and water more available in the flesh after the freezing step, the losses were greater.

For ocean ranched salmon, electrostatic smoking led to losses equivalent to those for smoking at $20^{\circ} \mathrm{C}$ or $30^{\circ} \mathrm{C}$. Given the very short smoking period and the absence of a drying step, this suggests that losses occurred during storage in the cold room $\left(12 \mathrm{~h}\right.$ at $\left.2^{\circ} \mathrm{C}\right)$ before the smoking operation. During this storage period, it is likely that dry-salted fillets reached a level of hygrometry similar to that maintained in the smoking unit during processing. 
As losses in brine after salting were lower, processing at $20^{\circ} \mathrm{C}$ and $30^{\circ} \mathrm{C}$ still had an effect on weight loss. In the case of fatter farm fish (groups B and C), in which water was less available, overnight storage at $+2^{\circ} \mathrm{C}$ was inadequate to produce a notable drying effect. Thus, drying continued during the drying-smoking step.

\subsubsection{Overall effect of salting and smoking conditions on yields after processing}

Regardless of the processing technique used, losses were higher with ocean ranched salmon, particularly when frozen (Table 1). This was essentially attributable to the size effect in direct relation with chemical composition. Figure 3 indicates the relative role of each processing step (salting and smoking) in the losses recorded. For samples smoked by the electrostatic method, losses were preponderant during salting.

For dry-salted ocean ranched salmon, losses were greater during the salting than the smoking step, whereas brine-salted samples showed greater losses during the smoking step. Moreover, when lipid content increased in the raw material, losses were smaller during the salting step.

Because of the organoleptic effect and product preservation, industrial specifications for "smoked finished products” generally recommend a water content in flesh of less than 65\% (Red Label standard, $n^{\circ} 33-90$ and $n^{\circ} 4$ 94, France). To obtain this result, producers must take account of the lipid content in raw material and the type of processes used, notably for salting. The choice of smoking parameters is determinant to avoid case-hardening of the product.

Fig. 3. Relative loss due to the salting in the global processing of salting and smoking (\%); Group $A(\square)=$ ocean ranched salmon (July 1998), Group B $(\square)$ = farmed salmon (October 1998), Group C ( $\square$ )= farmed salmon (April 1999); 1: dry salting and smoking at $20^{\circ} \mathrm{C}, 2$ : frozen raw material, dry salting and smoking at $20^{\circ} \mathrm{C}, 3$ : brine salting and smoking at $20^{\circ} \mathrm{C}, 4$ : dry salting and electrostatic smoking, 5: dry salting and smoking at $30^{\circ} \mathrm{C}$, 6: frozen raw material, dry salting and smoking at $30^{\circ} \mathrm{C}$, 7 : brine salting and smoking at $30^{\circ} \mathrm{C}$. The remaining relative loss is due to the smoking

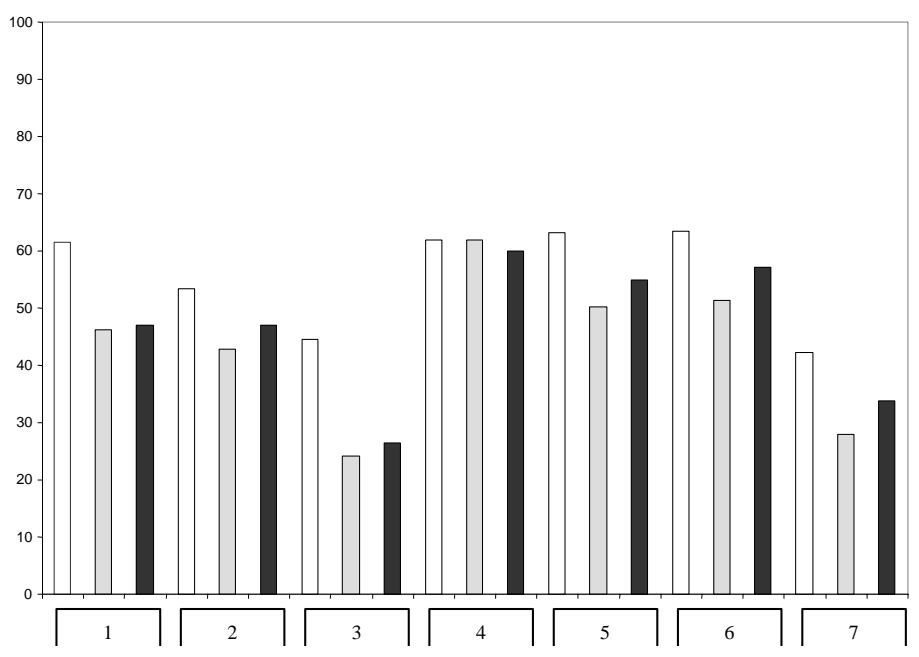




\subsection{Effect of smoking techniques or smoking temperature on quality parameters}

\section{Phenols content}

Phenol content allowed samples to be differentiated according to the smoking technique or smoking temperature (Figure 4). The lowest levels ( 0.2 to $0.55 \mathrm{mg} / 100 \mathrm{~g}$ of flesh) were observed for the electrostatic process. With a $20^{\circ} \mathrm{C}$ smoking temperature, mean phenol content in the groups ranged from 0.75 to $1.2 \mathrm{mg} / 100 \mathrm{~g}$, whereas a $30^{\circ} \mathrm{C}$ temperature involved levels of up to $3 \mathrm{mg} / 100 \mathrm{~g}$. Various reasons could account for these differences, including the type of smoke production and the type of smoke deposit. Despite the use of oak instead of beechwood with the electrostatic technique, processing time could not exceed $15 \mathrm{~min}$ in order to limit surface coloration. Therefore, phenols deposits were reduced. Moreover, the electrostatic field modifies the smoke compound ratio in the vapour phase, mainly by increasing the level of carbonyl compounds (Ruiter, 1979; Sirami, 1981). However, the $30^{\circ} \mathrm{C}$ temperature used with traditional smoking allows compounds with higher molecular weight, such as phenol compounds, to remain in the vapour phase mainly involved in the smoking effect (Potthast 1977, 1978; Foster, 1961a, 1961b, Girard,1988). Therefore, samples can reach high phenol values.

A raw material effect was also noted for the $30^{\circ} \mathrm{C}$ smoking technique, i.e. the lower the fat content in muscle, the higher was the phenol content in smoked samples. This may have been due to water availability relative to fat content. As noted above, very high surface desiccation leads to a reduction of solute diffusion and prevents interstitial water and lipid compounds from taking up smoke components (Clifford, 1980). The relative thinness of the fillet was another reason for higher phenol values in small fish. 
Fig. 4. Process effect on smoked salmon phenol content (mg/100 g). Group A $(\square)=$ ocean ranched salmon (July 1998), Group B $(\square)=$ farmed salmon (October 1998), Group C $(\square)=$ farmed salmon (April 1999); 1: dry salting and smoking at $20^{\circ} \mathrm{C}, 2$ : frozen raw material, dry salting and smoking at $20^{\circ} \mathrm{C}$, 3: brine salting and smoking at $20^{\circ} \mathrm{C}, 4$ : dry salting and electrostatic smoking, 5: dry salting and smoking at $30^{\circ} \mathrm{C}$, 6 : frozen raw material, dry salting and smoking at $30^{\circ} \mathrm{C}$, 7 : brine salting and smoking at $30^{\circ} \mathrm{C}$. Different letters indicate significant differences $(\mathrm{p}<0.05)$.

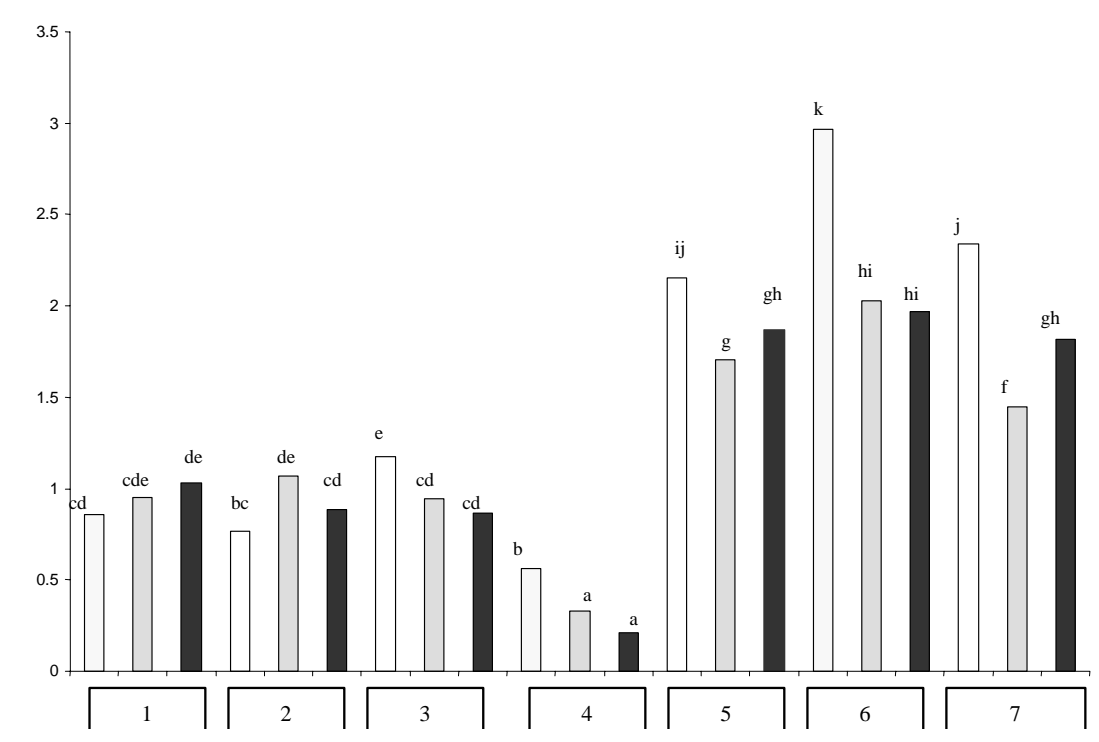

\section{Salt content}

Mean salt content in the groups of smoked fish ranged from 2.2 to $4 \mathrm{~g} / 100 \mathrm{~g}$ of wet flesh (Figure 5). Two main factors influenced salt uptake: the nature of the raw material (particularly size and composition) and the kind of salting technique used. As previously reported (Jason, 1965a; Jason \& Peters, 1973; Schwartzberg \& Chao; 1982, Storey, 1982), high fat content causes greater resistance to the transfer of an aqueous solute such as sodium chloride. This was true for our results, which showed salt uptake of $3.2 \%$ to $4 \%$ wet weight for leaner fish and $2.2 \%$ to $3.4 \%$ for fatter fish. Moreover, even though salting time had to be reduced for wild salmon (4 instead of $6 \mathrm{~h}$ ) to produce the same salt level in flesh, the small size of these ocean ranched fish allowed increased salt diffusion. Products salted in saturated brine generally have higher salt content than dry-salted samples because of better contact between surfaces and the salting medium. Brine is recommended for fatty fish because immersion limits exposure to oxidation phenomena in the air (Doe 1998). Salt content in smoked products was slightly higher for frozen raw material than fresh material, especially for leaner fish. This resulted from the freezing step, which modified cell structure slightly, increasing salt diffusivity. 
Fig. 5. Process effect on smoked salmon salt content (g/100 g). Group A ( $\square$ )= ocean ranched salmon (July 1998), Group B $(\square)=$ farmed salmon (October 1998), Group C $(\square)=$ farmed salmon (April 1999) 1: dry salting and smoking at $20^{\circ} \mathrm{C}, 2$ : frozen raw material, dry salting and smoking at $20^{\circ} \mathrm{C}$, 3 : brine salting and smoking at $20^{\circ} \mathrm{C}$, 4 : dry salting and electrostatic smoking, 5: dry salting and smoking at $30^{\circ} \mathrm{C}$, 6 : frozen raw material, dry salting and smoking at $30^{\circ} \mathrm{C}$, 7 : brine salting and smoking at $30^{\circ} \mathrm{C}$. Different letters indicate significant differences $(\mathrm{p}<0.05)$.

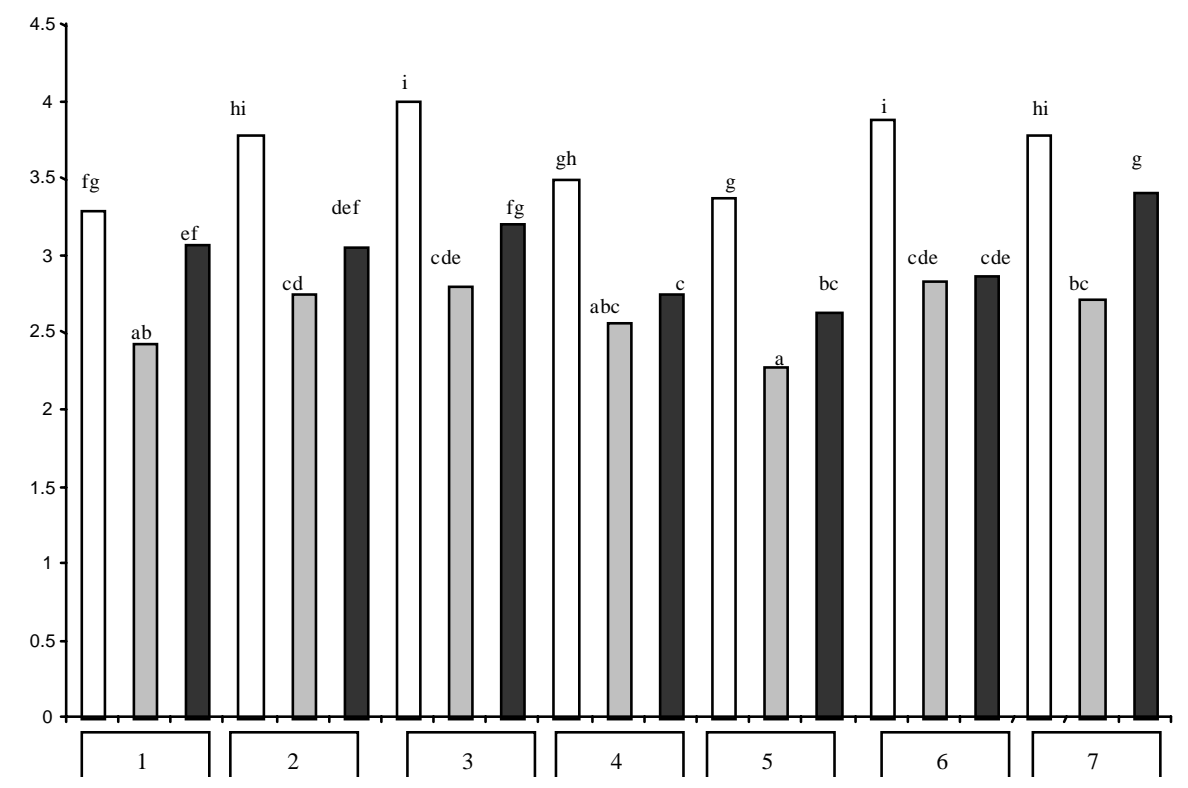

\section{Colour}

Colour measurements of raw and smoked fillet surface are given in Figures 6 and 7. Before processing, ocean ranched fish never fed pigments had lower $\mathrm{L}^{*}, \mathrm{a}^{*}$ and $\mathrm{b}^{*}$ values than the two farmed fish groups. There was no significant difference in colour parameters between the two reared fish groups. Smoking led to a reduction of a* values, as previously reported by Skrede \& Storebakken (1986), Choubert et al. (1992) and Rorå et al. (1998), an increase of $b^{*}$ values regardless of the raw material, and a reduction of $\mathrm{L}^{*}$ values (mainly for farmed fish). Choubert (1992) noted that smoking induces a loss of water, with an increase of carotenoid concentration and a decrease of hue and lightness. Ocean ranched salmon showed the lowest $a^{*}$ and $b^{*}$ values, but there was a colour difference between the two groups of farmed fish. Salmon from group C had lower values than those of group B, possibly because of fat content. Rorå (1998) found a significant correlation between fat content and colour measurements. In our study, fat content for groups B and C was respectively $20.0 \%$ and $16.8 \%$. Smoking temperature, however, did not affect parameters $\mathrm{a}^{*}$ and $\mathrm{b}^{*}$ in the same way. With a $30^{\circ} \mathrm{C}$ smoking temperature, b* values were greater than $\mathrm{a}^{*}$ values, i.e. products had a more intense yellowish tone, whereas with smoking at $20^{\circ} \mathrm{C}, \mathrm{a}^{*}$ values were higher and the red tone more intense. Regardless of the raw material, $\mathrm{b}^{*}$ values for raw and 
smoked fillets were higher when fish had been frozen. This freezing effect is not mentioned by Sheehan, O’Connor, Sheehy, Buckley \& FitzGerald (1998), who noted that colour modification depends on the kind of pigment used in fish diet. Despite the low smoking intensity for samples treated by the electrostatic technique, lightness was low compared to other samples. The level of carbonyl compounds involved in colour and to a lesser extent in flavour is higher with electrostatic smoking (Ruiter, 1979; Sirami, 1981), which could account for the difference of colour.

No colour difference between samples was observed relative to the salting technique.

Fig. 6. Colour measurements. $a^{*}$ and $b^{*}$ values of raw and smoked salmon. Colour system L*, a*, b*, CIE 1976 A: ocean ranched salmon (July 1998); B: farmed salmon (October 1998); C: farmed salmon (April 1999); r: fresh raw material, $\mathrm{r}^{*}$ : frozen raw material smoking procedures: $1=$ dry salting and smoking at $20^{\circ} \mathrm{C}, 2=$ frozen raw material, dry salting and smoking at $20^{\circ} \mathrm{C}, 3=$ brine salting and smoking at $20^{\circ} \mathrm{C}, 4=$ dry salting and electrostatic smoking, $5=$ dry salting and smoking at $30^{\circ} \mathrm{C}, 6=$ frozen raw material, dry salting and smoking at $30^{\circ} \mathrm{C}, 7=$ brine salting and smoking at $30^{\circ} \mathrm{C}$. Each point is the mean of 6 readings per fillet for 15 fish.

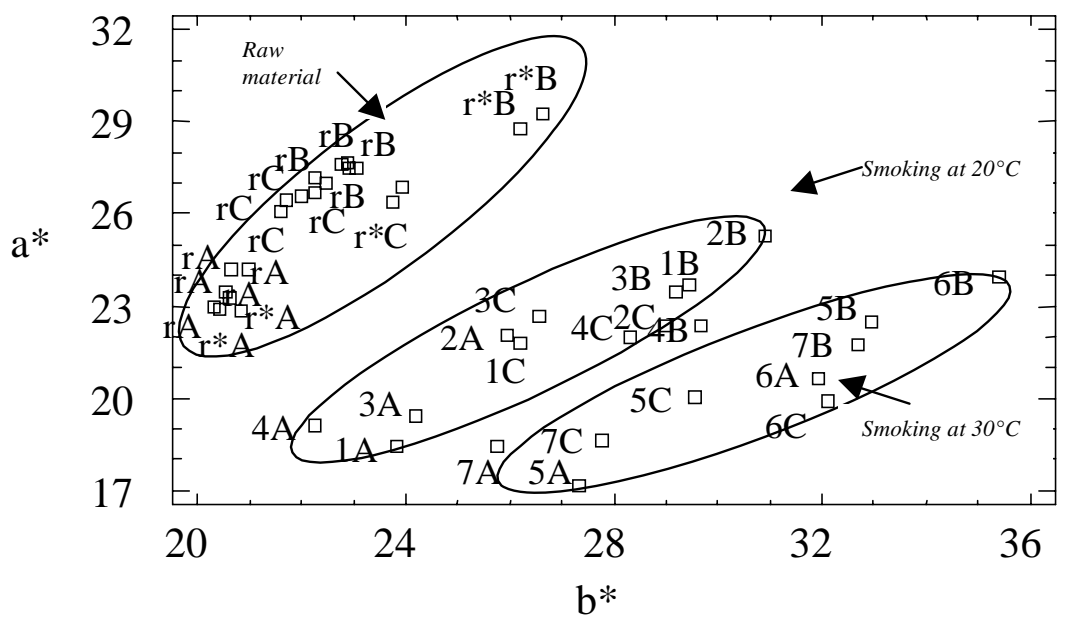


Fig. 7. Colour measurements on smoked salmon. L* and a* values. A: ocean ranched salmon (July 1998); B: farmed salmon (October 1998); C: farmed salmon (April 1999); r: fresh raw material; $r^{*}$ : frozen raw material smoking procedures $1=$ dry salting and smoking at $20^{\circ} \mathrm{C}, 2=$ frozen raw material, dry salting and smoking at $20^{\circ} \mathrm{C}, 3=$ brine salting and smoking at $20^{\circ} \mathrm{C}, 4=$ dry salting and electrostatic smoking, $5=$ dry salting and smoking at $30^{\circ} \mathrm{C}, 6=$ frozen raw material, dry salting and smoking at $30^{\circ} \mathrm{C}, 7=$ brine salting and smoking at $30^{\circ} \mathrm{C}$. Each point is the mean of 6 readings per fillet for 15 fish.

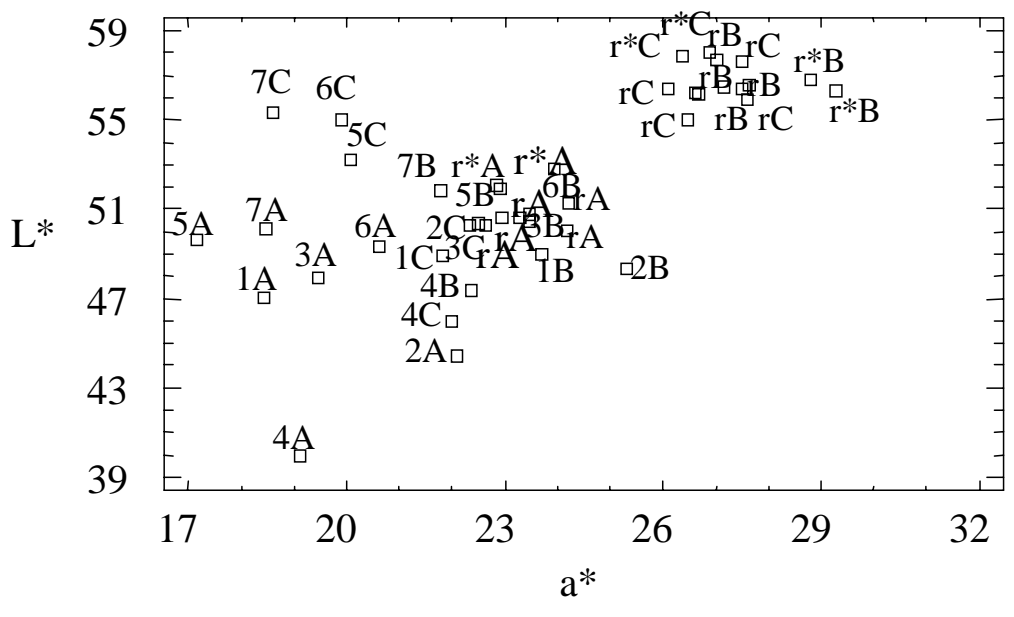

\section{Sensory properties}

Analysis of variance took the raw material effect, the process effect and the interaction between these two factors into account. Table 2 shows the F-value for each factor. For most sensory criteria, the results show that the process effect was higher than the raw material effect, except for colour descriptors (pink and orange) and firmness (for which the response level depended on the kind of raw material used).

Regardless of smoking temperature, a freezing step before processing affected the quality of smoked salmon, especially if fish were small and lean. Samples whose raw material was frozen had a saltier taste and less translucent slices. Their texture, which was close to that of the electrostatic smoked sample, was less firm and more pasty than that of other products. A texture slightly modified by freezing might actually increase the perception of salt more than the salt content level itself. The results of Sigurgisladottir et al. (2000) also show a significant effect of freezing/thawing on microstructure and texture. 
Table 2. Effect of the raw material and process on sensory properties. ${ }^{(1)}$ : F: value of Fisher test and significant level, NS: no significant difference, * significant difference at a level $\mathrm{p}<0.05$, $* *$ significant difference at a level $\mathrm{p}<0.01$, $^{* * *}$ significant difference at a level $\mathrm{p}<0.001{ }^{(2)}: 1$ : dry salting and smoking at $20^{\circ} \mathrm{C}, 2$ : frozen raw material, dry salting and smoking at $20^{\circ} \mathrm{C}$, 3 : brine salting and smoking at $20^{\circ} \mathrm{C}, 4$ : dry salting and electrostatic smoking, 5: dry salting and smoking at $30^{\circ} \mathrm{C}$, 6: frozen raw material, dry salting and smoking at $30^{\circ} \mathrm{C}$, 7: brine salting and smoking at $30^{\circ} \mathrm{C}$. ${ }^{(3)}$ : raw material A: ocean ranched salmon (July 1998); B: farmed salmon from Norway (October 1998); C: farmed salmon from Norway (April 1999)

\begin{tabular}{|c|c|c|c|c|c|}
\hline DESCRIPTORS & $\begin{array}{c}\text { Raw }^{(1)} \\
\text { material } \\
\text { effect } \\
2\end{array}$ & $\begin{array}{c}\text { Process }^{(1)} \\
\text { effect } \\
1\end{array}$ & $\begin{array}{c}\underset{\text { (1) }}{\text { Interaction }} \\
1-2\end{array}$ & $\begin{array}{c}\text { Multiple range tests }^{(2)} \\
\text { Duncan } \\
\text { for products }\end{array}$ & $\begin{array}{c}\text { Multiple range tests } \\
\text { Duncan }^{(3)} \\
\text { for raw material }\end{array}$ \\
\hline Odour: smoke intensity & $\begin{array}{l}3.0 \\
\text { NS }\end{array}$ & $\begin{array}{c}116.4 \\
* * *\end{array}$ & $\begin{array}{l}2.1 \\
\text { NS }\end{array}$ & $4^{\mathrm{a}} 1^{\mathrm{b}} 3^{\mathrm{b}} 2^{\mathrm{b}} 5^{\mathrm{c}} 7^{\mathrm{c}} 6^{\mathrm{c}}$ & $\mathrm{C}^{\mathrm{a}} \mathrm{A}^{\mathrm{ab}} \mathrm{B}^{\mathrm{b}}$ \\
\hline Odour: wood fire & $\begin{array}{l}0.94 \\
\text { NS }\end{array}$ & $\begin{array}{l}44.8 \\
* * *\end{array}$ & $\begin{array}{l}1.9 \\
\text { NS }\end{array}$ & $4^{\mathrm{a}} 2^{\mathrm{b}} 6^{\mathrm{bc}} 1^{\mathrm{bc}} 3^{\mathrm{cd}} 7^{\mathrm{d}} 5^{\mathrm{d}}$ & - \\
\hline Acrid smell of smoke & $\begin{array}{l}2.9 \\
\text { NS }\end{array}$ & $\begin{array}{l}52.8 \\
* * *\end{array}$ & $\begin{array}{l}2.6 \\
*\end{array}$ & $4^{\mathrm{a}} 1^{\mathrm{b}} 3^{\mathrm{bc}} 2^{\mathrm{c}} 5^{\mathrm{d}} 7^{\mathrm{d}} 6^{\mathrm{e}}$ & - \\
\hline Odour: toasted bread & $\begin{array}{l}53.2 \\
* * *\end{array}$ & $\begin{array}{l}42.1 \\
* * *\end{array}$ & $\begin{array}{l}19.6 \\
* * *\end{array}$ & $5^{\mathrm{a}} 7^{\mathrm{a}} 6^{\mathrm{ab}} 3^{\mathrm{b}} 1^{\mathrm{b}} 2^{\mathrm{c}} 4^{\mathrm{d}}$ & $\mathrm{C}^{\mathrm{a}} \mathrm{B}^{\mathrm{b}} \mathrm{A}^{\mathrm{c}}$ \\
\hline Odour: salmon/fish & $\begin{array}{l}2.9 \\
\text { NS }\end{array}$ & $\begin{array}{l}83.8 \\
* * *\end{array}$ & $\begin{array}{l}7.8 \\
* * *\end{array}$ & $6^{\mathrm{a}} 7^{\mathrm{a}} 5^{\mathrm{b}} 2^{\mathrm{c}} 3^{\mathrm{d}} 1^{\mathrm{d}} 4^{\mathrm{e}}$ & $\mathrm{A}^{\mathrm{a}} \mathrm{C}^{\mathrm{ab}} \mathrm{B}^{\mathrm{b}}$ \\
\hline Pink colour & 20.3 & $\begin{array}{l}7.6 \\
* * *\end{array}$ & $\begin{array}{l}7.9 \\
* * *\end{array}$ & $5^{\mathrm{a}} 7^{\mathrm{a}} 4^{\mathrm{ab}} 1^{\mathrm{bc}} 3^{\mathrm{c}} 2^{\mathrm{c}} 6^{\mathrm{c}}$ & $\mathrm{C}^{\mathrm{a}} \mathrm{B}^{\mathrm{b}} \mathrm{A}^{\mathrm{b}}$ \\
\hline Orange colour & $\begin{array}{l}36.7 \\
* * *\end{array}$ & $\begin{array}{l}14.2 \\
* * *\end{array}$ & $\begin{array}{l}15.1 \\
* * *\end{array}$ & $6^{\mathrm{a}} 3^{\mathrm{b}} 2^{\mathrm{b}} 7^{\mathrm{c}} 4^{\mathrm{c}} 1^{\mathrm{c}} 5^{\mathrm{c}}$ & $A^{a} B^{b} C^{c}$ \\
\hline Homogeneity of colour & $\begin{array}{l}0.02 \\
\text { NS }\end{array}$ & $\begin{array}{l}1.3 \\
\text { NS }\end{array}$ & $\begin{array}{l}1.2 \\
\text { NS }\end{array}$ & - & - \\
\hline Orange-edged slice & $\begin{array}{l}22.9 \\
* * *\end{array}$ & $\begin{array}{l}86.1 \\
* * *\end{array}$ & $\begin{array}{l}18.5 \\
* * *\end{array}$ & $3^{\mathrm{a}} 1^{\mathrm{b}} 7^{\mathrm{b}} 2^{\mathrm{c}} 5^{\mathrm{c}} 6^{\mathrm{d}} 4^{\mathrm{d}}$ & $\mathrm{A}^{\mathrm{a}} \mathrm{C}^{\mathrm{b}} \mathrm{B}^{\mathrm{b}}$ \\
\hline Translucent aspect & $\begin{array}{c}4.3 \\
*\end{array}$ & $\begin{array}{l}15.1 \\
* * *\end{array}$ & $\begin{array}{l}4.0 \\
* *\end{array}$ & $6^{\mathrm{a}} 2^{\mathrm{b}} 7^{\mathrm{bc}} 4^{\mathrm{bcd}} 5^{\mathrm{cd}} 3^{\mathrm{cd}} 1^{\mathrm{d}}$ & $A^{a} C^{a} B^{b}$ \\
\hline Fatty aspect & $\begin{array}{l}24.7 \\
* * *\end{array}$ & $\begin{array}{l}21.3 \\
* * *\end{array}$ & $\begin{array}{l}6.4 \\
* * *\end{array}$ & $7^{\mathrm{a}} 6^{\mathrm{a}} 5^{\mathrm{a}} 3^{\mathrm{b}} 1^{\mathrm{b}} 4^{\mathrm{b}} 2^{\mathrm{b}}$ & $A^{a} B^{b} C^{c}$ \\
\hline White stripes & $\begin{array}{l}9.8 \\
* * *\end{array}$ & $\begin{array}{l}15.2 \\
* * *\end{array}$ & $\begin{array}{c}2.8 \\
*\end{array}$ & $1^{\mathrm{a}} 2^{\mathrm{a}} 3^{\mathrm{a}} 4^{\mathrm{a}} 6^{\mathrm{b}} 5^{\mathrm{bc}} 7^{\mathrm{c}}$ & $\mathrm{B}^{\mathrm{a}} \mathrm{C}^{\mathrm{b}} \mathrm{A}^{\mathrm{b}}$ \\
\hline Flavour: smoke intensity & $\begin{array}{c}4.0 \\
*\end{array}$ & $\begin{array}{l}35.3 \\
* * *\end{array}$ & $\begin{array}{c}2.3 \\
*\end{array}$ & $4^{\mathrm{a}} 3^{\mathrm{b}} 1^{\mathrm{b}} 2^{\mathrm{b}} 7^{\mathrm{c}} 5^{\mathrm{cd}} 6^{\mathrm{d}}$ & $A^{a} B^{a b} C^{b}$ \\
\hline Flavour: wood fire & $\begin{array}{l}0.1 \\
\text { NS }\end{array}$ & $\begin{array}{l}63.0 \\
* * *\end{array}$ & $\begin{array}{c}2.8 \\
*\end{array}$ & $4^{\mathrm{a}} 3^{\mathrm{b}} 1^{\mathrm{b}} 6^{\mathrm{b}} 7^{\mathrm{bc}} 2^{\mathrm{bc}} 5^{\mathrm{c}}$ & - \\
\hline Salty taste & $\begin{array}{l}7.4 \\
* *\end{array}$ & $\begin{array}{l}28.6 \\
* * *\end{array}$ & $\begin{array}{l}5.5 \\
* * *\end{array}$ & $4^{\mathrm{a}} 3^{\mathrm{b}} 1^{\mathrm{b}} 5^{\mathrm{b}} 7^{\mathrm{bc}} 2^{\mathrm{bc}} 6^{\mathrm{d}}$ & $\mathrm{C}^{\mathrm{a}} \mathrm{B}^{\mathrm{b}} \mathrm{A}^{\mathrm{b}}$ \\
\hline Flavour: salmon/fish & $\begin{array}{l}1.9 \\
\text { NS }\end{array}$ & $\begin{array}{l}8.6 \\
* * *\end{array}$ & $\begin{array}{l}1.4 \\
\text { NS }\end{array}$ & $6^{\mathrm{a}} 7^{\mathrm{ab}} 5^{\mathrm{bc}} 3^{\mathrm{cd}} 2^{\text {cde }} 1^{\mathrm{de}} 4^{\mathrm{e}}$ & 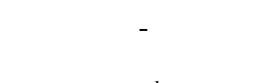 \\
\hline Firmness & $\begin{array}{l}41.8 \\
* * *\end{array}$ & $\begin{array}{l}29.5 \\
* * *\end{array}$ & $\begin{array}{l}14.9 \\
* * *\end{array}$ & $6^{\mathrm{a}} 4^{\mathrm{b}} 2^{\mathrm{c}} 3^{\mathrm{cd}} 1^{\mathrm{de}} 7^{\mathrm{e}} 5^{\mathrm{e}}$ & $A^{a} C^{b} B^{c}$ \\
\hline Melting texture & $\begin{array}{l}11.5 \\
* * *\end{array}$ & $\begin{array}{l}95.1 \\
* * *\end{array}$ & $\begin{array}{l}13.8 \\
* * *\end{array}$ & $6^{\mathrm{a}} 7^{\mathrm{b}} 5^{\mathrm{b}} 1^{\mathrm{c}} 3^{\mathrm{c}} 2^{\mathrm{d}} 4^{\mathrm{e}}$ & $A^{a} B^{a} C^{b}$ \\
\hline Fatty texture & $\begin{array}{l}16.1 \\
* * *\end{array}$ & $\begin{array}{l}88.2 \\
* * *\end{array}$ & $\begin{array}{l}8.1 \\
* * *\end{array}$ & $6^{\mathrm{a}} 7^{\mathrm{a}} 5^{\mathrm{b}} 1^{\mathrm{c}} 3^{\mathrm{cd}} 2^{\mathrm{d}} 4^{\mathrm{e}}$ & $\mathrm{A}^{\mathrm{a}} \mathrm{B}^{\mathrm{b}} \mathrm{C}^{\mathrm{b}}$ \\
\hline Pasty texture & $\begin{array}{l}8.6 \\
* *\end{array}$ & $\begin{array}{l}14.4 \\
* * *\end{array}$ & $\begin{array}{c}3.0 \\
*\end{array}$ & $7^{\mathrm{a}} 5^{\mathrm{a}} 3^{\mathrm{a}} 1^{\mathrm{a}} 2^{\mathrm{b}} 4^{\mathrm{bc}} 6^{\mathrm{c}}$ & $C^{a} B^{a} A^{b}$ \\
\hline
\end{tabular}

The smoking temperature or technique allowed products to be differentiated according to the intensity of smoke odour and flavour. From the lowest to the highest intensity, the panel ranked samples smoked by the electrostatic method first, followed by those smoked at $20^{\circ} \mathrm{C}$ and finally those smoked at $30^{\circ} \mathrm{C}$. These results are in agreement with those of Simon, Rypinsky \& Tauber (1966) and Girard (1988), who found that a higher temperature increases the deposit of smoke compounds. For products smoked by the electrostatic technique, the 
panel noted a special toasted bread odour in addition to low flavour intensity. These characteristics could be attributable to various factors, such as the kind of wood used, the smoke production method, pyrolysis temperature, smoke density, or smoking time (Holmes 1991, Cardinal et al., 1997). Moreover, this sample appeared to be fatter, and the texture was described as fatty and melting in the mouth. $20^{\circ} \mathrm{C}$ smoked samples also showed these characteristics but to a lesser extent. These sensory properties were observed, regardless of the raw material. It is noteworthy that muscle fat content could have modified sensory perception of smoked salmon, as reported by Sheehan et al. (1996). For the same fat level, the kind of smoking procedure may also modify the perception of texture.

Dry salting and brine salting did not appear to have much effect in changing the sensory properties of the products. The only modification observed was a more intense orange colour of slices when the dry-salting technique was used. However, the differences were generally very slight and not detectable by instrumental analysis performed on the fillet surface.

Figure 8 shows the main characteristics of each product in terms of principal component analysis performed on mean panel scores. The main interactions between the process and raw material were observed with toasted bread odour, for which differences between products were noted mainly for fish from group C. An increase in panel discriminative power for this particular score could account for these results. The process effect on colour (pink and orange colour, dark-edged slice) and translucence was more intense when salmon were leaner (groups A and C). For these fish, slices of previously frozen samples had a more intense pink colour. A storage temperature effect on colour loss and pigment concentration has already been noted by Andersen \& Steinsholt (1992) and Sheehan (1998). The electrostatic process gave samples with the most intense dark-edged slices, followed by samples smoked at $30^{\circ} \mathrm{C}$ and/or frozen before processing. Similar results were obtained with instrumental measurements in which the $\mathrm{L}^{*}$ value of the electrostatically smoked product was low compared to that of other samples (Figure 7). It is noteworthy that this criterion is considered to be of great interest with respect to consumer demand (Gormley, 1992).

Another process-raw material interaction was observed for the white stripe criterion. With a $30^{\circ} \mathrm{C}$ smoking temperature, stripes were more visible to the extent that the processed fish had a lower fat content. It would be of interest to determine whether processing parameters have an effect on lipid distribution and/or the connective tissue linking muscle fibres (Bremner, 1992) 
In summary, these results show that smoking conditions and preliminary treatment of fish (such as freezing) are major factors determining the sensory characteristics of smoked salmon, even though effects are reduced when fat content is increased in flesh.

Fig. 8. Projection of variables and samples in the 1-2 plane of principal component analysis on sensory descriptors. A: ocean ranched salmon (July 1998); B: farmed salmon from northern Norway (October 1998); C: farmed salmon from western Norway (April 1999) smoking procedures: 1 = dry salting and smoking at $20^{\circ} \mathrm{C}, 2$ = frozen raw material, dry salting and smoking at $20^{\circ} \mathrm{C}, 3=$ brine salting and smoking at $20^{\circ} \mathrm{C}, 4=$ dry salting and electrostatic smoking, $5=$ dry salting and smoking at $30^{\circ} \mathrm{C}, 6=$ frozen raw material, dry salting and smoking at $30^{\circ} \mathrm{C}, 7=$ brine salting and smoking at $30^{\circ} \mathrm{C}$.

\section{Component 2 (20.2\%)}

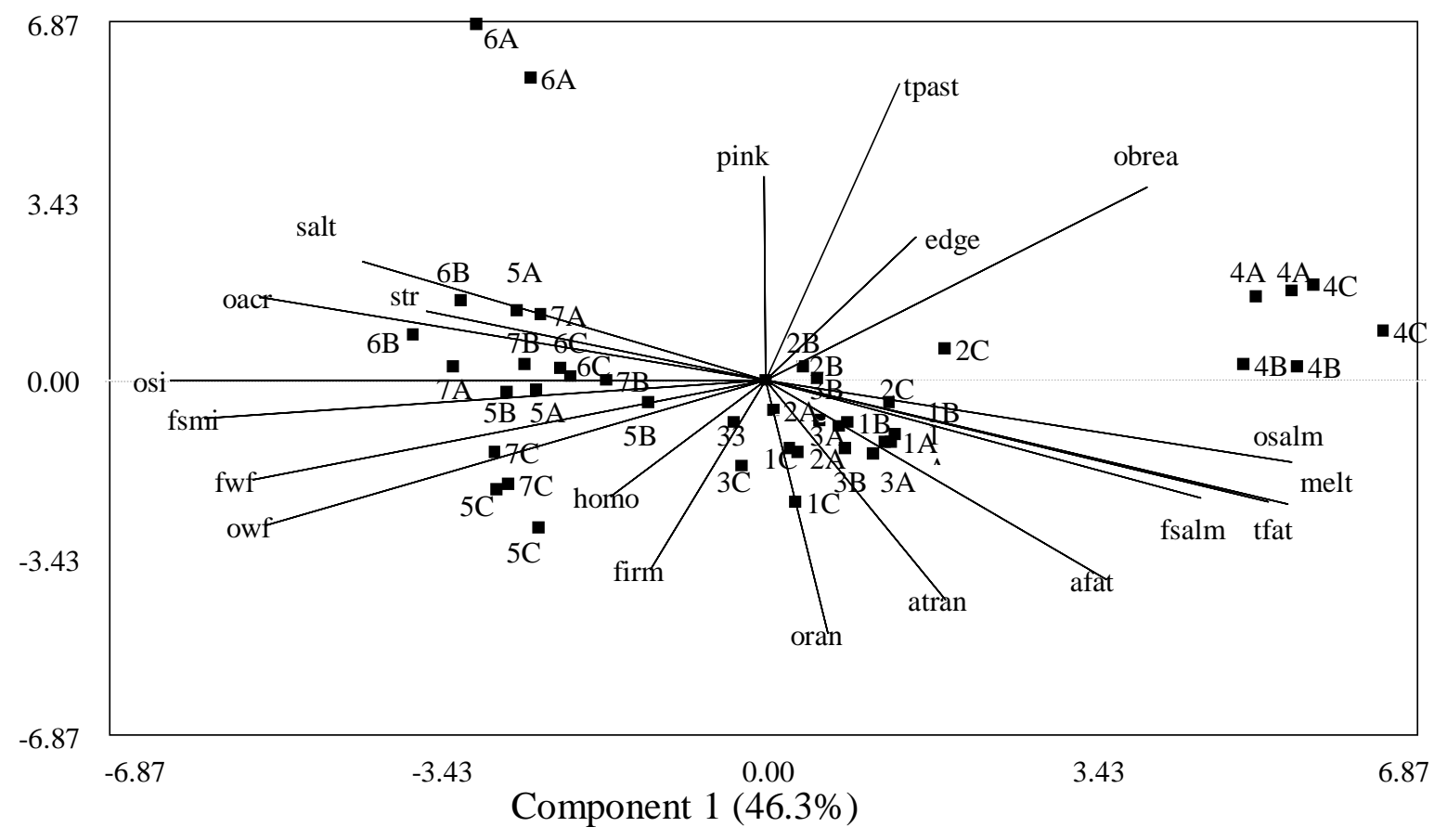

\section{Conclusion}

This study confirms the results of previous work concerning the relation between fat content and yields or the final characteristics of smoked salmon. It also dealt with the nature of the interaction between the process used and the initial raw material characteristics. It would appear that losses after processing increase when fish have reduced lipid content (less than 10\%) as compared to fatter fish, especially in the case of frozen fish. A fat fish is less sensitive to a freezing step, and the yield after processing is increased, regardless of the kind of smoking procedure used. Nevertheless, for this type of raw material, smoking temperature needs to be reduced to prevent too high a desiccation of the surface (which generally produces intense surface colouring but little diffusion of smoke compounds into the flesh). 
For the three raw materials analysed, the processes studied showed the same kind of effect on smoked salmon properties, but with greater differences between treatments in the case of small lean fish.

A freezing step should be avoided in order to limit losses during the processing of fish with little fat (brine salting and a smoking temperature of $30^{\circ} \mathrm{C}$ are recommended). However, fatter fish require a lower smoking temperature to prevent possible case-hardening or a colour problem. Analysis of the effect of smoking temperature or the kind of smoke deposit showed a gradient in fat texture perception according to the process used, regardless of the kind of raw material. Samples subjected to electrostatic smoking showed more fat texture, less in those smoked at $20^{\circ} \mathrm{C}$ and the least in those smoked at $30^{\circ} \mathrm{C}$. Smoking conditions would appear to have a greater impact than muscle fat content on texture evaluation. A specialised study is needed to determine the effect of temperature or the electrostatic field on lipid structure.

\section{Acknowledgements}

This research was performed with the financial support of the European Union in the context of FAIR project

CT-95-1101. The authors are grateful for the assistance of the project co-ordinator, Dr H. Hafsteinsson (Matra, Technological Institute of Iceland). 


\section{REFERENCES}

Andersen, U.B. \& Steinsholt, K. (1992) Deepfrozen salmon: Differences in quality after storage at different temperatures following different storage periods. Norwegian Journal of Agricultural Sciences 6, 211-215.

Aursand, M., Bleivik B., Rainuzzo, J. R., Jorgensen L. \& Mohr V. (1994) Lipid distribution and composition of commercially farmed Atlantic salmon (Salmo Salar) Journal of the Science of Food and Agricultural 64 (2), 239-248.

Bardin, J. C., Desportes, G., Knockaert, C. \& Vallet, J. L. (1997) Improvement in devices for electrostatic smoking of meat products. French Patent No. 9708177, filing date: June 25.

Beltran A. \& Moral A. (1991) The effects of fat contents and storage temperature on the storage life of smoked sardine fillets (Sardina pilchardus W.) prepared from frozen sardine. Food Chemistry 42 (3), 347-356.

Berg, T., Erikson, T. \& Nordtvedt, T. S. (1997) Rigor mortis assessment of Atlantic Salmon and effects on stress. Journal of Food Science 62(3), 439-446.

Bimbenet, J. J. (1978) Le séchage dans les industries agricoles et alimentaires. Cahiers du Génie Industriel Alimentaire. Sepaic (Ed.), Paris.

Bohuon, P. (1995) Déshydratation-Imprégnation-Immersion en solutions ternaires : Etude des transports d’eau et de solutés sur gel et produits d'origine animale. PhD thesis, University of Montpellier 2.

Boury, M.(1934) Etudes sur le salage du poisson. Revue des travaux de l'Institut des Pêches Maritimes 26, $195-221$.

Bremner, H. A.(1992) Fish flesh structure and the role of collagen-its post-mortem aspects and implications for fish processing. In: Quality Assurance in the Fish Industry. Huss, Jakobsen and Liston (Ed.), Elsevier, Amsterdam, 39-62.

Cardinal, M., Berdagué, J. L., Dinel, V., Knockaert, C. \& Vallet J. L.(1997) Effet de différentes techniques de fumage sur la nature des composés volatils et les caractéristiques sensorielles de la chair de saumon. Science des Aliments 17, 679-696.

Chan, W. S., Toledo, R. T., Deng, J. (1975) Effect of smokehouse temperature, humidity and air flow on smoke penetration into fish muscle. Journal of Food Science 40, 240-243.

Cheftel J.C. \& Cheftel H. (1977) Traitements physiques. In Introduction à la biochimie et à la technologie des aliments. Technique et Documentation, Lavoisier, Paris, 199-219. 
Choubert, G., Blanc J. M. and Courvalin C. (1992) Muscle carotenoid content and colour of farmed rainbow trout fed astaxanthin or canthaxanthin as affected by cooking and smoke-curing procedures. International Journal of Food Science and Technology 27, 277-284.

Clifford., M.N. (1980) Smoking of foods. Process Biochemistry 15, 8-11.

Collignan, A., Knockaert, C., Raoult-Wack, A. L., Vallet, J.L. (1992). Procédé et dispositif de salage séchage et de fumage à froid de produits alimentaires carnés. Patent No. 92/08958.

Collignan, A., Knockaert, C., Raoult-Wack, A. L. \& Vallet, J. L. (1993) Process for salting-drying and smoking cold meat products and a device for carrying this out. Patent No. 93430009.6, filing date: July 10.

Dieuzeide, R. \& Novella, M. (1951) Essai sur la technique des salaisons de poissons. Station Expérimentale d’Aquiculture de Catiglione, Inspection Générale de l’Agriculture, Bulletin No. 167, Algiers.

Doe, P.E., Sikorski, Z., Haard, N., Olley, J. \& Sun Pan, B., (1998) Basic Principles. In Fish Drying \& Processing. Production and Quality. Peter E. Doe (Ed.) Technomic Publishing Co., Lancaster, 13-46.

Dussap, G. \& Gros, J.B. (1980) Diffusion-sorption model for the penetration of salt in pork and beef muscle. Food Process Engineering, Applied Science Publishers, Amsterdam 407-411.

Foster, W.W. (1961) Studies of the smoking process for food. 1-The importance of vapours. Journal of the Science of Food and Agricultural 5, 363-374.

Foster, W.W. (1961) Studies of the smoking process for food. 2-The role of smoke particles. Journal of the Science of Food and Agricultural 9, 635-644.

Girard, J.P. (1988) La fumaison : Technologie de la viande et des produits carnés . Ed Lavoisier 6,171-214

Gormley, T.R. (1992) A note on consumer preference of smoked salmon colour. Irish Journal of Agricultural and Food Research 31, 199-202.

Hempel E. (1998) Another decade of growth for salmon. Seafood International, August, 27-31.

Hempel E. (1999) Bright future lies ahead for salmon. Norway: Industry continues to grow. Seafood International, June, 22-23.

Hillestad, M., Austreng, E. \& Johnsen, F. (1995) Product quality in fast growing adult Atlantic Salmon fed diets differing in fat content. Aquaculture Europe 95. European Aquaculture Society. Special Publication No. 23, 180-181.

Holmes.A (1991) BNF Nutrition Bulletin 16,66-72.

Horner, W.F.A. (1993) Preservation of fish by curing (drying, salting and smoking) In Fish Processing Technology. Hall G.M.(Ed.) Black Academic \& Professional, VCH Publishers, New York, 30-72. 
Indrasena, W.M., Hansen, L.T., Gill, T.A. (2000) Effect of cold-smoking and drying on the textural properties of farmed Atlantic salmon (Salmo salar). Journal of Aquatic Food Product Technology 9(1), 47-64.

Jason, A. C. (1965a) Effects of fat content on diffusion of water in fish muscle. Journal of Science and Food Agriculture 16 ,281-288.

Jason, A. C. (1965b) Drying and dehydration Excerpt from “Fish as Food” Borgstrom G. Ed. Academic Press London. 111,1-54.

Jason, A. C. \& Peters, G.R. (1973) Analysis of bimodal diffusion of water in fish muscle. Journal of physics. D. Applied physics. 6, 512-521.

Knockaert, C. (1990) Le fumage du poisson. Service de la documentation et des publications, Ifremer, Brest.

Korhonen, R.W., Reagan, J.O., Carpenter, J.A., Campion, D.R., \& Stribling, K.V. (1978) Effect of initial ham quality and other variables on processing yield and smoke deposition. Journal of Food Science 43, 856-859.

Kunert, J., Qannari, E.M. (1999) A simple alternative to generalized procrustes analysis: Application to sensory profiling data. Journal of Sensory Studies 14, 197-208.

Label No. 33-90. Saumon Ecossais. Ministère de l’Agriculture, de la Pêche et de l’Alimentation. Bureau des Labels et des Certifications de Produits, Paris.

Label No. 4-94. Saumon Fumé. Ministère de l'Agriculture, de la Pêche et de l’Alimentation. Bureau des Labels et des Certifications de Produits, Paris.

Le Gall, J. (1938) Le fumage du poisson. Revue des Travaux de l'Institut des Pêches Maritimes, 11, 59-106.

Monfort M.C. (1999) Increasing the market for smoked salmon. Seafood International September, 33-37.

NF V 45-065 (1995) Poisson transformé. Saumon fumé. Association Française de Normalisation (AFNOR), Paris.

NF V-09-105 (1995) Directives générales pour l'implantation de locaux destinés à l'analyse sensorielle. In Contrôle de la qualité des produits alimentaires - Analyse sensorielle

NF ISO 11035 (1994). Sensory Analysis - Identification and selection of descriptors for establishing a sensory profile by a multidimensional approach. In Contrôle de la qualité des produits alimentaires- Analyse sensorielle, AFNOR, Paris.

Ponting, J.D . (1973) Osmotic dehydration of fruits. Recent modifications and applications. Proc.Biochem 8,18-20.

Potthast, K. (1977) Determination of phenols in smoked meat products. Acta Alimentaria Polonica 3(3), 189-193. 
Potthast, K. (1978) Smoking methods and their effects on the content of 3,4-benzo(a)pyrene and other constituents of smoke in smoked meat products. Die Fleischwirtschaft 58(3), 371-375.

Roberts R. (1998) Atlantic salmon - The European Scene. Aquaculture Magazine March/April, 26-36.

Rorå, A. M. B., Kvale, A., Morkore, T., Rorvik, K.-A., Steien S. H. \& Thomassen, M.S. (1998) Process yield, colour and sensory quality of smoked Atlantic Salmon in relation to raw material characteristics. Food Research International 31, 8, 601-609.

Ruiter A. (1979) Color of smoked foods. Food Technology 33,54-63.

Rye, M. (1991) Prediction of carcass composition in Atlantic salmon by computerized tomography. Aquaculture 99, 35-48.

Saurel, R., Raoult-Wack, A. L. , Rios, G., \& Guilbert, S. (1994) Mass transfer phenomena during osmotic dehydration of apple. Part 2: Frozen plant tissue. International Journal of Food Science and Technology 29, 543550.

Schwartzberg, H. G. \& Chao, R. Y. (1982) Solute diffusivities in leaching process. Food Technlogy. 36(2), 73-86.

Sheehan, E.M., O’Connor, T.P., Sheehy, P.J.A., Buckley, D.J., \& FitzGerald, R. (1996) Effect of dietary fat intake on the quality of raw and smoked salmon. Irish Journal of Agricultural and Food Research 35, 37-42.

Sheehan, E.M., O’Connor, T.P., Sheehy, P.J.A., Buckley, D.J., \& FitzGerald, R. (1998) Stability of astaxanthin and canthaxanthin in raw and smoked Atlantic salmon (Salmo salar) during frozen storage. Food Chemistry 63 (3), 313-317.

Sigholt, T., Erikson, U., Rustad, T., Johansen, S., Nordtvedt, T.S. \& Seland, A. (1997) Handling stress and storage temperature affect meat quality of farm-raised Atlantic salmon. Journal of Food Science 62 (4), 898-905.

Sigurgisladottir, S., Torrissen, O., Lie, O., Thomassen, M. \& Hafsteinsson, H. (1997) Salmon Quality: Methods to determine the quality parameters. Reviews in Fisheries Science, 5(3), 223-252.

Sigurgisladottir, S., Ingvarsdottir, H., Torrissen, O.J., Cardinal, M. \& Hafsteinsson, H. (2000) Effects of freezing/thawing on the microstructure and the texture of smoked Atlantic salmon (Salmo salar). Food Research International 33, 857-865.

Simon, S., Rypinski, A.A. \& Tauber, F.W. (1966) Water-filled cellulose casings as model absorbents for wood smoke. Food Technology 20, 114-118. 
Sivertsvik, M.(1994) Processing and Preservation Technology: The influence of different packaging materials during storage of whole frozen Atlantic salmon. Norconserv. Institute of Fish Processing and Preservation Technology.

Sirami J. (1981) Mise en application de processus de fumage. Viandes et Produits Carnés 2, 8-13.

Skrede, G., \& Storebakken, T. (1986) Instrumental colour analysis of farmed and wild atlantic salmon when raw, baked and smoked. Aquaculture, 53, 279-286.

Soudan , F. (1955) Aspects chimiques du salage de la morue, Ph D Thesis, University of Nantes.

Stone, H., Sidel, J.L., Oliver S., Woolsey, A., \& Singleton, R.C. (1974) Sensory Evaluation by Quantitative Descriptive Analysis. Food Technology, 28(11), 24-34.

Stone, H., \& Sidel, J.L. (1985) Sensory evaluation practices. Academic Press Inc., New York.

Storey, R.M. (1982) Smoking. In Fish handling and processing. Aitken, A., Mackie, I.M., Merritt, J.H. \& Windsor, M.L.(2 ${ }^{\text {nd }}$ ed.), Torry Research Station, Aberdeen. 98-114.

Torrissen, O. (1995) Norwegian salmon culture: 1 million tons in 2005? Aquaculture Europe 19(4), 6-11.

Wang, D., Tang, J., \& Correia L. R. (2000) Salt diffusivities and salt diffusion in farmed Atlantic Salmon muscle as influenced by rigor mortis. Journal of Food Engineering 43,115-12. 